\title{
RESEARCH FUNDING OF NURSING EDUCATION IN THE PUBLIC SECTOR
}

\author{
LR Uys, University of KwaZulu-Natal; \\ D van Rooyen, Nelson Mandela Metropolitan University, \\ C Sheppard, University of Johannesburg
}

\begin{abstract}
The public Nursing Colleges are interested in becoming Higher Education Institutions in order to be able to offer the new qualifications gazetted by the SANC. If they become part of the subsidy system of the Department of Higher Education and Training, it is important to understand what the implications are for their funding. The aim of this article is to explore the impact on College finances if they become registered Higher Education Institutions (HEls) and move to the subsidy system.

A survey was done of four colleges representing three provinces to establish their current funding and student group. It was then calculated what their subsidy would have been in the same year if they were in the higher education system. It was found that some of the colleges would have done better and some worse in a new system. This variation exists even between the two colleges from the same province.
\end{abstract}

Keywords: Research; NRF

\section{Introduction}

Universities and Nursing Colleges, which often include schools and campuses, form the public nursing education sector in South Africa. These two components have very different funding mechanisms. The Universities are funded through a system of subsidies by the Department of Higher Education and Training (DHET) (2011), while the colleges are funded through a budget made available by the Provincial Departments of Health.

In the past, the programmes of the Colleges were accredited by the SA Nursing Council (SANC), but the SANC can no longer accredit Higher Education Programmes which are not accredited by the Higher Education Quality Committee. The new nursing programmes to be offered by the Nursing College from 2014 will therefore not be accredited. To be able to have their programmes accredited by the Higher Education Quality Committee (HEQC), colleges have to adhere to nineteen criteria against which the programmes are accredited. The input criteria indicate the need for education-focused policy and management. This poses a challenge for the colleges as they operate as institutions under the health department and not as juristic persons with control over their own finances and policies. It may be very difficult under the current conditions for a college to achieve accreditation for its programmes.

According to the Green Paper for Post-School Education and Training (2012), the relationships between the colleges in government departments other than DHET and other public institutions are very weak and should be strengthened and made more coherent. 
The first step will be a close engagement with the Departments of Health to explore the relationship between them and the DHET with regard to their nursing colleges. This is especially relevant to the recognition of qualifications, quality assurance and staff qualifications. The DHET (2012) suggested two possible options for strengthening these colleges, and rebuilding or reopening colleges, as part of a coherent post-school system. One option is that the colleges remain in the current department, but are strengthened, especially with regard to quality assurance. The other is that responsibility for these colleges shifts to the DHET, but that colleges still retain a close working relationship with the Department of Health (DOH). Whichever option is adopted, the priority is to develop a coherent framework that allows these colleges to fit into the post-school system, including the Higher Education Management Information System (HEMIS) and the funding system.

\section{Funding for University Nursing Schools}

The funding of schools of nursing at South African universities is done in accordance with the requirements of the Higher Education Act, 1997 (Act 101 of 1997) and the funding framework (Government Gazette, No 25824 of 9 December 2003) approved by both the Ministers of Education and of Finance. To enable universities to plan, the Department makes incremental, rather than drastic changes in the funding formula. Universities are expected to deliver the high level of professional and occupational skills, research and innovation required for economic growth and development.

The DHET subsidy has three major components:

1. Block grant-input subsidy, which is based on the number of students enrolled at the institution. The subsidy is higher for students who are more senior and for post-graduate qualifications.

2. Block grant-output subsidy, which is based on how many students complete their qualifications and is higher if the student qualifies in less rather than more time.

3. Block grant-research output subsidy which is based on the research products of academics and students of the university, mainly the number of articles published in approved research journals.

4. Earmarked grants made for specific projects or items such as infrastructure and student loans. In the case of nursing, the DHET makes a Clinical Training Grant available for the clinical training of undergraduate nursing students.

The Presidency's Performance Monitoring and Evaluation (PME) targets set for the Minister of Higher Education and Training focus on specific areas that must align with the DHET's strategic goals and objectives. At undergraduate level, these targets focus on increased outputs of graduates and diplomates in engineering, life and physical sciences, human and animal health sciences and initial teacher education. At postgraduate level, these targets centre upon increased outputs of honours' graduates, research master's graduates, doctoral graduates and post-doctoral fellowships. To achieve the human resource targets of the country, the subsidy favours certain disciplines, of which nursing is one, so that the input and output subsidies for nursing students are higher than, for instance, that of a student in a Bachelor's degree in Arts.

The calculation of the block grants is based on the HEMIS data. This is an electronic data base which is updated regularly through University submissions of their actual performance, and these figures are carefully audited. Input funding is based on enrolment targets, set by and for each institution, with only a $2 \%$ difference allowed between enrolment target and actual enrolment. 
The first three subsidy streams are relatively predictable, and schools of nursing can boost their own subsidies by enrolling more students, improving output, enlarging the proportion of post-graduate students they register and increasing the numbers of research publications. Although the special subsidies are sometimes made for more than one year, they are not always predictable and may be withheld or changed from year to year.

Universities also have access to two other major sources of funding: student fees, often supported by the National Student Financial Aid System (NSFAS), and donations and grants (often through funding for research).

\section{Funding for Provincial Nursing Colleges}

Most nursing colleges function according to provincial legislation, which is different for every province. Based on this legislation, nursing colleges are funded from the provincial health budgets. Such funding is based on a budget submitted by the college management and depends on the allocation of funds, firstly to the Provincial Department of Health, and then to the specific college. These budgets are not based on any norms or standards, and therefore do not automatically increase with increased activity. No management information system for nursing colleges exists, either provincially or nationally.

The provinces have also benefited from the Health Professional Training and Development Grant (HPTD) provided by the fiscus for the clinical training of health professionals. However, there is no transparency on how these grants are used by different provinces, and great variations exist. The colleges are not awarded such grants as additional funding; instead, the grants may be used to provide their annual financial allocation.

One of the focus areas of the Nursing Compact derived from the Nursing Summit of 2011 is nursing education. A recommendation is to be tabled to the Minister of Health, Dr. A Motsoaledi, on how to implement the resolution that nursing education at college level should become a national competence. Input for this resolution was based on, among other arguments, the presentation of $\mathrm{Dr}$ S. Mkhize, who mentioned in his presentation that:

- Nursing Education be declared a national competence: this is provided for under section 21 of the Higher Education Act, 1997 (Act No. 101 of 1997);

- $\quad$ The option to use section 97 and 99 of the Constitution of South Africa, 1996 (Act No 108 of 1996) which allows the President by proclamation to

- transfer the function of one member of the cabinet (i.e. a minister) to another member - s97;

- assign a duty of a cabinet member to a member of a provincial executive council (i.e. an MEC) s99.

There are a few possible solutions to this dilemma:

A national solution: The Department of Agriculture and Fisheries (DAF) faced a similar problem. They have twelve Agricultural Colleges with only about 1500 students in total. Some of these colleges offer national diplomas and some B-degrees. All these programmes have now been accredited by the HEQC. However, to make legal provision for managing these higher education institutions, the DAF is in the 
process of developing a National Agricultural Training Institutes Bill 2012. This Bill is currently going through a process of consultation.

The National Agricultural Training Institutes Bill makes provision for the declaration of current agricultural colleges as Agricultural Training Institutes and describes all the aspects usually covered in the statutes of a university: establishment, governance, funding, management, human resources' issues, student affairs, quality assurance and promoting teaching and learning. This draft makes provision for a National Council of Agricultural Institutes of SA at national DAF level to manage the oversight of the Agricultural Institutes.

A provincial solution: In the Eastern Cape, the Lilitha College of Nursing faced similar problems and, working with the Nelson Mandela Metropolitan University's School of Nursing and their provincial government, they have created provincial legislation that enables them to function legally. They have also created a policy infrastructure for the college and have recently applied for the accreditation of their first programmes with the Higher Education Quality Committee.

Most students at nursing colleges are either employed in student posts by the provincial health department, with a reasonable salary, or they have bursaries for more or less the same amount. However, the student fees in most cases are very low, making an almost negligible contribution to the running of the colleges. These students clearly do not have access to the NSFAS funding.

Similarly, since the colleges are not on the same subsidy system as the universities, they do not receive funding for research outputs. In most cases this does not matter at the moment, since they are usually not active in research. However, it does mean that colleges do not have a financial incentive for research activity.

\section{Aim and Research Questions}

The public nursing colleges are interested in becoming Higher Education Institutions in order to be able to offer the new qualifications gazetted by the SANC. If they become part of the subsidy system of the DHET, it is important to understand what the implications are for their funding. The question is what the impact on college finances will be if they become registered Higher Education Institutions (HEI) and move to the subsidy system. Will colleges get more or less money? What proportion of their income will they have to get from student fees?

For this analysis it is assumed that, at the beginning, the output grant for research at nursing colleges will be insignificant. The current student fee income is also not considered since it is very low and in some cases there are no student fees.

\section{Methodology}

To answer the research questions, the annual (2010) enrolment and graduate data from four provincial nursing colleges was obtained from the college principals, to whom the aim of the study was explained. 
Sampling: Four colleges were purposely chosen since they included all the public nursing training in their own province. They also represented both rural and urban campuses, as well as both single and multiple campus colleges.

Data collection: The information was obtained based on a letter to the principals asking for student and financial information. Information dealt with the levels of students and the duration and level of the programmes for which they were registered, as well as the number of students who completed their studies during the year. The financial information dealt with the budget they received for the year 2010 and how much of this was allocated to student funding.

Data analysis: A management information expert at a local university was provided with the enrolment data and asked to calculate what the subsidy income of these four colleges would have been, had they been functioning within the DHET subsidy system. Although it is not possible to predict with $100 \%$ certainty how the qualifications would be interpreted by the DHET for subsidy purposes, a number of comparative qualifications were decided upon by the researchers for data analysis and these are shown in the appropriate table.

Ethical issues: The study was approved by the Research Committee of FUNDISA which acts as the Ethics Committee for the organization. The principals were fully informed about the aim of the study and participated on a voluntary basis. The colleges were kept anonymous to protect them from rash actions based on the research results.

\section{Results}

The input and output results of all four colleges are summarized in table 6.1. The comparative qualification in the university system is provided in brackets in column one. The student numbers vary from 676 to 4255 and the qualifying student numbers vary between 183 and 1933. 
Table 6.1: Enrolments of four provincial nursing colleges in South Africa for $\mathbf{2 0 1 0}$

\begin{tabular}{|c|c|c|c|c|}
\hline & $\begin{array}{l}\text { College of } \\
\text { Nursing A }\end{array}$ & \begin{tabular}{ll|} 
College & of \\
Nursing B &
\end{tabular} & $\begin{array}{ll}\text { College of } \\
\text { Nursing C }\end{array}$ & $\begin{array}{l}\text { College of } \\
\text { Nursing D }\end{array}$ \\
\hline Student intake in 2010 & 3792 & 4255 & 799 & 676 \\
\hline 4-yr. Diploma Programme (UG) & 2372 & 2350 & 613 & 539 \\
\hline Bridging Course (2 yrs) (UG) & 197 & 953 & 81 & 40 \\
\hline Enrolled Nurses (2 yrs) (UG) & 615 & 272 & 0 & 0 \\
\hline Enrolled Auxiliaries (1 yr) (UG) & 402 & 0 & 0 & 0 \\
\hline $\begin{array}{l}\text { One yr Clinical Nursing Science } \\
\text { Health Assessment Treatment and } \\
\text { Care (Hons) }\end{array}$ & 0 & 0 & 49 & 45 \\
\hline $\begin{array}{l}\text { Post Basic Programmes }\left(\begin{array}{ll}1 & y r\end{array}\right) \\
\text { (Hons) }\end{array}$ & 89 & 270 & 0 & 0 \\
\hline One Year Midwifery (Hons) & 117 & 410 & 31 & 16 \\
\hline $\begin{array}{l}\text { Advanced Midwifery and Neonatal } \\
\text { Science (Hons) }\end{array}$ & 0 & 0 & 18 & 11 \\
\hline $\begin{array}{l}\text { Diploma in Psychiatric Nursing } \\
\text { (Hons) }\end{array}$ & 0 & 0 & 0 & 10 \\
\hline Operating Theatre (Hons) & 0 & 0 & 7 & 0 \\
\hline Diploma in Child Care (Hons) & 0 & 0 & 0 & 8 \\
\hline Diploma in Critical Care (Hons) & 0 & 0 & 0 & 7 \\
\hline Graduates from 2010 & 1247 & 1933 & 253 & 183 \\
\hline R 425 (4-year diploma) (UG) & 325 & 489 & 133 & 110 \\
\hline R 683 (Bridging Course) (UG) & 56 & 412 & 35 & 13 \\
\hline R 212 (Post basics) (Hons) & 156 & 222 & 16 & 11 \\
\hline R 2176 (Enrolled Nurses) (UG) & 241 & 14 & 0 & 0 \\
\hline $\begin{array}{l}\text { R } 2175 \text { (Enrolled Nursing assistants) } \\
\text { (UG) }\end{array}$ & 332 & 404 & 0 & 0 \\
\hline R 254 (Midwifery) (Hons) & 112 & 319 & 25 & 3 \\
\hline $\begin{array}{l}\text { R } 880 \text { Diploma in Psychiatric } \\
\text { Nursing (Hons) }\end{array}$ & 0 & 26 & 0 & 4 \\
\hline $\begin{array}{l}\text { R } 48 \text { (Clinical Assessment, } \\
\text { Diagnosing and Treatment) (Hons) }\end{array}$ & 25 & 47 & 37 & 42 \\
\hline Operating Theatre (Hons) & 0 & 0 & 7 & 0 \\
\hline Diploma in Child Care (Hons) & 0 & 0 & 0 & 0 \\
\hline Diploma in Critical Care (Hons) & 0 & 0 & 0 & 0 \\
\hline
\end{tabular}


The budget provided for College A for 2010/11 was R292.677m and for College B R449.792m. The budget for College C for 2010/11 was R79.234m and for College D R78.209m. College A also received R2.885m from the HPTD Grant which comes directly from the Treasury to the Provincial Department of Health for the training of health professionals.

It is important to recognize that, unlike the budgets of nursing schools at universities, the budget allocation to nursing colleges includes the bursaries or salaries of students. In 2010, students at College A received salaries of about $R 6000$ per month ( $x 13$ per annum $=R 78000$ ), but in the meantime this has changed to bursaries and cut to R3000 per month (x 12 per annum). Most of the other categories of learners were already in $\mathrm{DOH}$ posts and were provided for in their workplace budgets. The system in College B changed in the middle of 2010.

\section{Subsidy Estimations for the Nursing Colleges}

Based on the comparative qualifications offered at university nursing schools and their DHET input and output subsidies, the estimated subsidy which these colleges could expect, were they part of the subsidy system, was calculated. The data from one college (A) is provided in tables 6.2 and 6.3 as an example.

Table 6.2: Nursing College A as per 2010 student intake

\begin{tabular}{|c|c|c|c|c|c|c|c|}
\hline & $\begin{array}{l}\text { College } \\
\text { of } \\
\text { Nursin } \\
\text { g A }\end{array}$ & $\begin{array}{l}\text { Estimated } \\
\text { Enrolled } \\
\text { FTEs* }\end{array}$ & $\begin{array}{l}\text { Weight } \\
\text { for } \\
\text { CESM* } \\
*\end{array}$ & $\begin{array}{l}\text { Weight } \\
\text { for Level }\end{array}$ & $\begin{array}{l}\text { Teaching } \\
\text { Input Units } \\
\text { (TIU) }\end{array}$ & $\begin{array}{l}\text { Rand Value of } \\
\text { TIU }\end{array}$ & $\begin{array}{l}\text { Estimated Teaching } \\
\text { Input Subsidy }\end{array}$ \\
\hline Current students & 3792 & 3071.52 & & & 11002.64 & R $10,619.00$ & R 116,836,981.07 \\
\hline $\begin{array}{l}\text { 4-yr Diploma } \\
\text { Programme (UG) }\end{array}$ & 2372 & 1921.32 & 3.5 & 1 & 6724.62 & R 10,619.00 & R 71,408,739.78 \\
\hline $\begin{array}{l}\text { Bridging Course } \\
\text { (2 yrs) (UG) }\end{array}$ & 197 & 159.57 & 3.5 & 1 & 558.50 & R $10,619.00$ & R 5,930,658.41 \\
\hline $\begin{array}{l}\text { Post Basic } \\
\text { Programmes (1 } \\
\text { yr) (Hons) }\end{array}$ & 89 & 72.09 & 3.5 & 2 & 504.63 & R $10,619.00$ & R 5,358,665.97 \\
\hline $\begin{array}{l}\text { One Year } \\
\text { Midwifery (UG) }\end{array}$ & 117 & 94.77 & 3.5 & 1 & 331.70 & R 10,619.00 & R 3,522,269.21 \\
\hline $\begin{array}{l}\text { Enrolled Nurses } \\
\text { (2 yrs) (UG) }\end{array}$ & 615 & 498.15 & 3.5 & 1 & 1743.53 & R 10,619.00 & R 18,514,491.98 \\
\hline $\begin{array}{l}\text { Enrolled } \\
\text { Auxiliaries (1 yr) } \\
\text { (UG) }\end{array}$ & 402 & 325.62 & 3.5 & 1 & 1139.67 & R $10,619.00$ & R $12,102,155.73$ \\
\hline
\end{tabular}

* FTE: Full-Time Equivalent student

** CESM: Classification of Educational Subject Matter 
Table 6.3: Nursing College A as per 2010 Graduates

\begin{tabular}{|c|c|c|c|c|c|}
\hline & $\begin{array}{l}\text { Number of } \\
\text { graduates }\end{array}$ & $\begin{array}{l}\text { Teaching } \\
\text { Output } \\
\text { Unit } \\
\text { Weight }\end{array}$ & $\begin{array}{l}\text { Weighted } \\
\text { Teaching } \\
\text { Output Units }\end{array}$ & $\begin{array}{l}\text { Rand Value per } \\
\text { Unit }\end{array}$ & $\begin{array}{l}\text { Estimated } \\
\text { Teaching } \\
\text { Output Subsidy }\end{array}$ \\
\hline $\begin{array}{l}\text { Students who } \\
\text { graduated in } 2010\end{array}$ & 1222 & & 948.5 & R 18,308.11 & R $17,365,242.34$ \\
\hline $\begin{array}{l}\text { R } 425 \text { (4 yr } \\
\text { diploma) (UG) }\end{array}$ & 325 & 1.5 & 487.5 & R $18,308.11$ & R 8,925,203.63 \\
\hline $\begin{array}{l}\text { R } 212 \text { (Post basics) } \\
\text { (Hons) }\end{array}$ & 156 & 0.5 & 78 & R 18,308.11 & R $1,428,032.58$ \\
\hline $\begin{array}{l}\text { R } 2176 \text { (Enrolled } \\
\text { Nurses) (UG) }\end{array}$ & 241 & 0.5 & 120.5 & R 18,308.11 & R 2,206,127.26 \\
\hline $\begin{array}{l}\text { R } 2175 \text { (Enrolled } \\
\text { Nursing assistants) } \\
\text { (UG) }\end{array}$ & 332 & 0.5 & 166 & R 18,308.11 & R 3,039,146.26 \\
\hline $\begin{array}{l}\text { R } 683 \text { (Bridging } \\
\text { Course) (UG) }\end{array}$ & 56 & 0.5 & 28 & R 18,308.11 & R 512,627.08 \\
\hline $\begin{array}{l}\text { R } 254 \text { (Midwifery) } \\
\text { (UG) }\end{array}$ & 112 & 0.5 & 56 & R 18,308.11 & R $1,025,254.16$ \\
\hline R 880 (Hons) & 0 & 0.5 & 0 & R 18,308.11 & R 0.00 \\
\hline $\begin{array}{l}\text { R } 48 \text { (Clinical } \\
\text { assessment, } \\
\text { diagnosing and } \\
\text { treatment) (Hons) }\end{array}$ & 25 & 0.5 & 12.5 & R 18,308.11 & R 228,851.38 \\
\hline
\end{tabular}

When the income and output subsidies are combined with the possible Clinical Training Grant these colleges might be receiving, the resultant income is reflected in table 6.4. College A also received R2.885m from the HPTD Grant which comes directly from the Treasury to the Provincial Department of Health for the training of health professionals and that was included in their income. However, for the other provinces the contribution of this grant could not be identified and was therefore omitted.

Table 6.4: Totals for Four Nursing Colleges

\begin{tabular}{|l|l|l|l|}
\hline College & $\begin{array}{l}\text { Estimated input and output } \\
\text { subsidy without clinical } \\
\text { grant }\end{array}$ & Estimated clinical grant & $\begin{array}{l}\text { Total subsidy with Clinical } \\
\text { Grant }\end{array}$ \\
\hline A & $\mathrm{R} 134,202,223.40$ & $\mathrm{R} 3,815,793.70$ & $\mathrm{R} 138,018,017.10$ \\
\hline B & $\mathrm{R} 162,871,968.23$ & $\mathrm{R} 3,780,402.70$ & $\mathrm{R} 166,652,370.93$ \\
\hline C & $\mathrm{R} 30,611,033.58$ & $\mathrm{R} 986,122.07$ & $\mathrm{R} 31,597,155.65$ \\
\hline D & $\mathrm{R} 25,274,272.37$ & $\mathrm{R} 867,079.60$ & $\mathrm{R} 26,141,351.97$ \\
\hline
\end{tabular}




\section{Comparison between current DOH and estimated DHET income}

The comparison between the actual income from the $\mathrm{DOH}$ and the estimated income from the DHET is summarized in table 6.5. This is a mixed picture, with two of the four colleges receiving less via the current funding system than they would with the DHET system, and two receiving more. The variance is quite high in the two colleges which would receive less under a new system ( $B$ and $D$ ), with College $B$ only receiving $51 \%$ of its current income and College $D$ receiving $66 \%$.

Table 6.5: Total Funding from DOH and DHET per College for 2010

\begin{tabular}{|c|c|c|c|c|c|}
\hline College & $\begin{array}{l}\text { Actual } \\
\text { Income: } \\
\text { DOH }\end{array}$ & $\begin{array}{l}\text { Student } \\
\text { funding }\end{array}$ & $\begin{array}{l}\text { Estimated Income } \\
\text { DOH excluding } \\
\text { student funding }\end{array}$ & $\begin{array}{l}\text { Estimated } \\
\text { Income: DHET }\end{array}$ & Variation \\
\hline College A & R $295.562 \mathrm{~m}$ & R185.016m* & R110 546m & R $138.018 m$ & $+\mathrm{R} 46.998 \mathrm{~m}$ \\
\hline College B & R 449.732m & R120.860m & R328 872m & R $166.652 m$ & $-\mathrm{R} 162$ 220m \\
\hline College C & $\mathrm{R} \quad 79.234 \mathrm{~m}$ & R55 164m & R24 070m & $\mathrm{R} \quad 31.597 \mathrm{~m}$ & $+\mathrm{R} 7527 \mathrm{~m}$ \\
\hline College D & R $78.209 m$ & R38 334m & R39 875m & R $26.141 \mathrm{~m}$ & $-R 13734 m$ \\
\hline
\end{tabular}

* Calculated based on 4-year diploma students only, so it may be higher.

\section{Discussion}

The difference between the four colleges indicates that the financial provision for nursing education across the provinces is extremely variable. On the one had it raises the question as to whether the two that are receiving more than they would receive from the DHET are performing better than the other two; that is, whether their funding levels are more appropriate. If this is the appropriate level of funding, how can the income of the others be augmented? On the other hand, it may mean that some colleges are over-funded. This question can only be answered by doing a comparative analysis of the adherence of the four colleges to the Higher Education Quality Committee's process standards and criteria and their output. It is recommended that a normative subsidy system be implemented for college nursing education to create a more accountable and equitable system.

It should be remembered that the income of university nursing schools is augmented annually by student fees and by research output grant income. While it would probably take some years for nursing colleges to increase their research output to a level that would make a significant contribution to their income, realistic student fees could make an immediate difference. It is hard to argue that a student who receives a salary/bursary cannot make a realistic contribution to his/her own education. This is especially true in the face of the fact that all other Higher Education students have to make such a contribution, even if they have to borrow the money via NSFAS. Obtaining a nursing education is an investment in the future, since nursing graduates are seldom (if ever) unemployed. Currently, most of the public colleges in South Africa do not require student fees and, if they do, these are often unrealistically low, for instance R600 per annum. In most provinces the system also does not allow such funds to be kept in the college and used for nursing education. Instead, the funds become part of the financial income of the provincial government and are spent accordingly. This does not allow for a 
businesslike approach to funding college business. It is recommended that a more appropriate student fee system be developed and implemented in nursing colleges.

It is important for policy-makers to take the finances into consideration when planning for the future of public nursing colleges. Already private nursing colleges do not prepare registered (professional) nurses by direct entry, since they find this qualification too expensive. Instead, they concentrate on a step-wise training system, starting with the training of staff nurses who then bridge to become registered nurses. In the Green Paper (2012) the DHET proposes to strengthen the college system and to review the subsidy system. This could go a long way to addressing the financial issues with regard to nursing colleges. However, this should be done before any drastic changes are made to the public nursing college system, which could lead to a slump in the production of nurses, either in terms of quality or quantity or both.

\section{Conclusion}

While the subsidy income of nursing colleges cannot be predicted with total accuracy, it is possible to estimate what the implications for such colleges would be should they become part of the DHET. At the moment, such a move seems to be financially impossible within current financial arrangements. It is strongly recommended that nursing colleges become part of the HEMIS system and that a norms-based funding system be developed and implemented.

\section{Reference}

Department of Agriculture and Fisheries. 2012. Draft National Agricultural Training Institutes Bill . Pretoria: DAF.

Department of Education. 1997. Higher Education Act, 1997 (Act 101 of 1997). Pretoria: DOE.

Department of Education. 2003. Government Gazette, No 25824 of 9 December 2003.

Department of Higher Education and Training. 2012. Green Paper for Post-School Education and Training. Pretoria: DHE\&T.

Minister of DHE\&T. 2011. Ministerial Statement on University Funding: 2012/13 and 2013/14. Pretoria: DHE\&T.

Mkize, S. 2011. The Input of CPAS to the Nursing Summit. Unpublished document submitted to DOH. Uys, L.R. and Klopper, H.C. 2012. Trends in Nursing 2012. Pretoria: FUNDISA.

Van Rooyen, D., Ricks, E., and Morton, D. 2012. Status of research-related activities of South Africa's university nursing schools. In Uys, L. R. and Klopper, H. C. (Eds) 2012 Nursing Trends 2012. Pretoria FUNDISA, p 129 to 152 